\title{
PENERAPAN METODE FONIK DALAM PEMBELAJARAN BAHASA INGGRIS BAGI ANAK USIA DINI
}

\author{
Oleh: Nina Khayatul Virdyna \\ (Dosen Jurusan Tarbiyah Prodi Tadris Bahasa Inggris, Nina.nanang.kazganilma@gmail.com)
}

\begin{abstract}
Abstrak:
Bahasa Inggris bukan hanya menjadi bahasa asing atau bahasa internasional yang dipelajari di sekolah mulai tingkat PAUD sampai tingkat berikutnya.

Kecenderungan masyarakat akan penguasaan bahasa asing tersebut, membuat berbagai lembaga pendidikan saling berlomba membuat program yang memasukkan Bahasa Inggris sebagai salah satu keahlian yang dikembangkan, khususnya bagi anak usia dini. Untuk itu, beberapa lembaga PAUD atau TK berlomba untuk memasukkan Bahasa Inggris dalam kurikulum mereka. Persoalannya adalah pelajaran Bahasa Inggris untuk PAUD menuntut penanganan khusus yang berbeda dengan pelajaran kepada kelompok umur yang lain. Metode fonik adalah tawaran model pembelajaran bahasa untuk anak usia dini dan dikembangkan dengan mengoptimalkan seluruh keterampilan berbahasa, menyimak, berbicara, menulis dan membaca. Metode ini menekankan pada pelajaran alfabet yang diberikan terlebih dahulu kepada anak-anak, mempelajari nama-nama huruf dan bunyinya. Setelah mereka mempelajari bunyi huruf mereka akan mulai merangkum beberapa huruf tertentu untuk membentuk kata-kata.
\end{abstract}

Kata kunci:

Metode Fonik, Pembelajaran Bahasa Ingrris, PAUD

Pendahuluan

Bahasa Inggris dalam perkembangannya saat ini bukan hanya menjadi bahasa asing atau bahasa internasional yang harus dipelajari di sekolah mulai dari tingkat sekolah anak usia dini sampai sekolah tingkat atas bahkan tingkatan selanjutnya. Keahlian berbahasa asing ini memang diperlukan untuk menguasai ilmu pengetahuan, memiliki pergaulan luas dan karir yang baik. Hal ini membuat semua orang dari berbagai kalangan termotivasi untuk mengusai Bahasa Inggris.
Kecenderungan masyarakat akan penguasaan bahasa asing tersebut, membuat berbagai lembaga pendidikan saling berlomba membuat program yang memasukkan Bahasa Inggris sebagai salah satu keahlian yang dikembangkan.

Keyakinan bahwa semakin dini usia anak dalam belajar bahasa inggris maka semakin cepat anak itu menerima bahasa dengan baik. Untuk itulah bahasa Inggris sudah diperkenalkan secara luas mulai usia dini baik di sekolah-sekolah formal maupun nonformal. Maka seperti yang sudah di 
sebutkan di atas beberapa lembaga PAUD atau TK berlomba-lomba untuk memasukkan bahasa inggris dalam kurikulum mereka.

Mengingat anak usia dini adalah individu penerima bahasa paling baik. Tapi bukan juga pembelajaran dengan tingkat emosional yang stabil dan memiliki tingkat konsentrasi yang pendek maka untuk mengajarkan mereka bahasa inggris diperlukan metode dan teknik yang mempuni. Berbagai penelitian telah membuktikan bahwa usia dini merupakan usia paling peka belajar bahasa. Maka atas dasar itulah pelajaran Bahasa Inggris untuk anak-anak usia dini mulai TK dan Sekolah Dasar sudah secara luas ditawarkan di berbagai sekolah di perkotaan.

Persoalannya adalah bahwa
pengajaran Bahasa Inggris untuk
kelompok usia semacam ini menuntut penanganan khusus yang berbeda dengan pelajaran kepada kelompok umur yang lain. Perlu di adakan metode khusus mengajar bahasa inggris yang menyenangkan untuk anak usia dini. Ini terbukti dari kenyataan bahwa tidak semua guru mampu dan berhasil mengajar anak-anak. Boleh jadi karena dalam mengajar anak dibutuhkan kemampuan menyelami dunia anak dan kemampuan memasuki dunia mereka yang masih sangat penuh dengan imajinasi.

Melalui lingkungan yang dapat merangsang anak untuk belajar di usia emasnya, di mana otak anak berkembang pesat. Seberapa besar rangsangan yang diberikan maka sebesar itu pulalah potensi otak tergugah. Di masa ini pula menjadi saat yang tepat bagi pembentukan karakter dasar anak.

Metode fonik adalah sebuah model pembelajaran bahasa yang ditujukan untuk anak usia dini dan dikembangkan dengan mengoptimalkan seluruh ketrampilan berbahasa, menyimak, berbicara, menulis dan membaca ${ }^{1}$. Metode ini adalah metode membaca dengan bunyi huruf (phone), tidak dieja seperti zaman saya belajar membaca dulu. Misalnya mengenalkan "a[ei]" for apple[eipel]", "b[beh] for boy[boi] dst. Sehingga dengan fonik anak tidak hanya bisa membaca tapi juga bisa berbahasa Inggris dengan baik dan benar².

\section{Pentingnya Belajar Bahasa Bagi Anak Usia Dini}

Pada perkembangannya, saat ini bahasa Inggris tidak dianggap sesuatu yang asing lagi bagi pelajar di Indonesia. Dulu Bahasa Inggris dianggap sebagai mata pelajaran yang sulit untuk dimengerti. Namun seiring dengan perkembangan tekhnologi yang menuntut kebutuhan untuk dapat

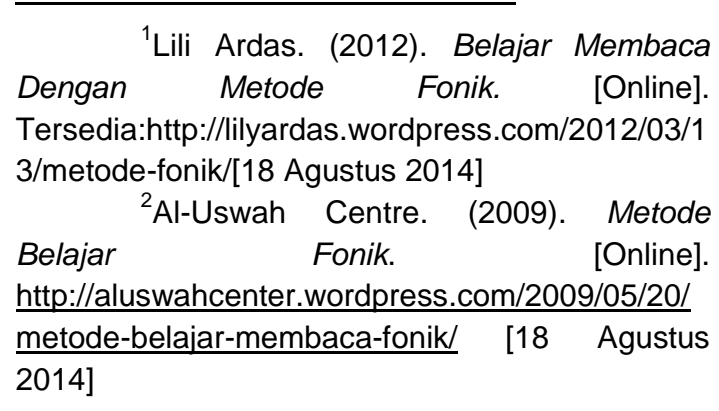


menguasai Bahasa Inggris, kurikulum di dunia pendidikan mulai mengalami perubahan. Bahasa Inggris yang semula diperkenalkan kepada siswa SMP, sekarang sudah diperkenalkan kepada siswa SD bahkan siswa yang masih duduk di bangku Taman Kanak-Kanak atau play group sudah mulai diperkenalkan dengan Bahasa asing ini walau konteks pembelajarannya masih belajar sambil bermain.

Mempelajari Bahasa Inggris sebagai Bahasa kedua perlu dipelajari sejak usia dini sebelum individu memasuki masa pubertas. Seorang ahli Bahasa Inggris, Chomsky mengatakan , "there was a neurologically based "critical period", which complete mastery of language, but it is no longer possible, because it will end around the onset of puberty". Menurut Chomsky, seorang individu mempunyai masa penting (periode sensitif) untuk dapat dengan mudah dan cepat menguasai Bahasa, yang disebut dengan "critical period" pada saat individu tersebut belum memasuki masa pubertas. Ketika masa pubertas itu datang maka "critical period" memudar sehingga akan mengalami kesulitan untuk menguasai Bahasa asing tersebut ${ }^{3}$. Pakar Bahasa Inggris lainnya, Plunket melakukan observasi terhadap anak-anak dari keluarga imigrasi yang datang dari negara lain dan menetap di USA. Penelitian tersebut menemukan bahwa anak-anak imigrasi

${ }^{3}$ Chomsky, N; Skinner, B. F. (1959). "A Review of B. F. Skinner's Language Verbal Behavior" (Linguistic Society of America) tersebut yang belum mencapai masa pubertas, dapat berbicara dalam Bahasa Inggris dengan pronunciation yang bagus seperti native speaker. Sedangkan orang tuanya tidak dapat mencapai kemampuan seperti anakanaknya. Memang para orang tua tersebut dapat berbicara dengan lancar tetapi mereka mempunyai kesulitan dalam pronunciation, pemilihan kata, dan grammar yang seharusnya digunakan ${ }^{4}$.

Pelatihan bahasa Inggris di usia dini memiliki peran yang begitu penting terhadap tumbuh kembang seorang anak. Dalam beberapa penelitian disebutkan bahwa, begitu pentingnya stimulasi pendidikan anak sejak usia dini, lebih lagi saat usia 4 tahun dimana seorang anak telah mencapai separuh dari kemampuan kecerdasannya, dan pada usia 8 tahun yang telah mencapai $80 \%$. Baru kemudian setelah usia 8 tahun, tanpa melihat bentuk pendidikannya dan lingkungan yang diperoleh, kemampuan kecerdasan anak hanya dapat diubah sebanyak $20 \%$. Dari hasil penelitian tersebut berarti bahwa selama usia 4 tahun pertama dari kehidupan anak dan dari usia 4-8 tahun kecerdasan anak. Amatlah baik sejak dini mengajari anak membaca. Bahkan saat anak masih berusia delapan bulan, membacakan cerita untuknya dapat membantunya ketika beranjak dewasa.

\footnotetext{
${ }^{4}$ Plunkett Kim (1998). Rethinking innateness: A Connectionist Perspective on Development. The MIT Press
} 
"Meski diusia tersebut belum bisa berkata-kata, namun upaya ini mempunyai efek yang luar biasa bagi pertumbuhan kecerdasan si anak.

Pembelajaran bahasa inggris penting untuk diajarkan sejak dini, hal ini dikemukakan Trawick Smith (dalam Andriani, 2011) menyatakan bahwa: Ketika seorang anak belajar untuk berbicara dua atau lebih bahasa dirinya akan cenderung untuk memilih salah satu diantara bahasa tersebut untuk menggambarkan sebuah objek atau konsep ${ }^{5}$. Jika dua bahasa digunakan di dalam rumah, maka anak usia 18 bulan ke atas akan cenderung menggunakan kedua bahasa tersebut dan memilih serta dapat mengenal bahasa yang dipergunakan masing - masing anggota keluarga. Pernyataan tersebut didukung oleh banyak ahli yang menyatakan bahwa sangat baik bagi seorang anak untuk belajar bahasa keduanya sebelum ia berusia 10 tahun, artinya kemampuan belajar bahasa kedua anak akan lebih baik jika dia belajar sebelum usia 10 tahun. Maka dari itu, bahasa Inggris sebaiknya dikenalkan sejak dini, karena pada usia dini merupakan masa keemasan dimana segala sesuatu dapat diserap dengan mudah dan cepat.

Apabila telah mencapai masa pubertas akan banyak kendala yang dihadapi sehingga hasil yang diperoleh tidak maksimal, terutama dalam

\footnotetext{
${ }^{5}$ Latifah Nurfauziah, 2013. Penggunaan Teknik Talking Stick Dalam Meningkatkan Penguasaan Kosakata Bahasa Inggris Anak Usia Dini Universitas Pendidikan Indonesia |repository.upi.edu|perpustakaan.upi.edu
}

menguasai pronunciation atau lafal mengucapkan bahasa asing tersebut. Seorang ahli Bahasa Inggris, Lenneberg (1967:116) mengatakan, "there was a neurologically based "critical period", which complete mastery of language, but it is no longer possible, because it will end around the onset of puberty". Menurut Lenneberg, seorang individu mempunyai masa penting (periode sensitif) untuk dapat dengan mudah dan cepat menguasai Bahasa, yang disebut dengan "critical period" pada saat individu tersebut belum memasuki masa pubertas. Ketika masa pubertas itu datang maka "critical period" memudar sehingga akan mengalami kesulitan untuk menguasai Bahasa asing tersebut. Pakar Bahasa Inggris lainnya, Lightbown \& Spada (1999:60) melakukan observasi terhadap anak-anak dari keluarga imigrasi yang datang dari negara lain dan menetap di USA. Penelitian tersebut menemukan bahwa anak-anak imigrasi tersebut yang belum mencapai masa pubertas, dapat berbicara dalam Bahasa Inggris dengan pronunciation yang bagus seperti native speaker. Sedangkan orang tuanya tidak dapat mencapai kemampuan seperti anakanaknya. Memang para orang tua tersebut dapat berbicara dengan lancar tetapi mereka mempunyai kesulitan dalam pronunciation, pemilihan kata, dan grammar yang seharusnya digunakan ${ }^{6}$.

${ }_{\text {Nunung }}^{6}$ wijayanti
http://nunungwidijantie.blogspot.com/2012/06/nor
mal


Bukan sesuatu yang salah jika Anda sebagai orang tua memperkenalkan bahasa lain disamping bahasa Ibu, dalam hal ini bahasa Inggris kepada anak-anak. Meskipun usia mereka tergolong dini, misalnya ketika baru belajar berbicara. Jangan khawatir dulu anak-anak akan bingung dalam menentukan bahasanya nanti, sebab secara otomatis otak mereka bisa membedakan mana bahasa yang dominan digunakan dan mana bahasa yang tidak dominan.

Penguasaan kosakata bahasa Inggris anak di PAUD sejauh ini sebatas pada mengenal bilangan 1-10 dalam bahasa Inggris, serta beberapa warna dalam bahasa Inggris. Padahal usia 4 -5 tahun merupakan saat berkembang pesatnya penguasaan tugas pokok dalam berbicara yaitu menambah kosakata, menguasai penambahan pengucapan kata dan menggabungkan kata menjadi kalimat (Hurlock, 1990:113) ${ }^{7}$. Penguasaan kosakata anak meningkat pesat ketika ia belajar kata kata baru dan arti - arti baru. Jadi, beberapa kosakata sekarang sudah lebih variatif sesuai dengan kurikulum dan perkembangan zaman.

\section{Cara Mengajarkan Bahasa Inggris Pada Anak dalam Kehidupan sehari- hari}

\footnotetext{
${ }^{7}$ Latifah Nurfauziah, 2013. Penggunaan Teknik Talking Stick Dalam Meningkatkan Penguasaan Kosakata Bahasa Inggris Anak Usia Dini Universitas Pendidikan Indonesia |repository.upi.edu perpustakaan.upi.edu
}

Belajar Bahasa Inggris mulanya merupakan kegiatan belajar yang dilakukan di dalam ruangan (indoor learning). Namun sekarang, belajar Bahasa Inggris dapat dilakukan di mana saja dan kapan saja dengan menggunakan media apa pun. Di samping pelajaran yang diterima di dalam kelas, siswa dapat belajar Bahasa Inggris di tempat- tempat kursus dan lembaga pendidikan non-sekolah lainnya atau dirumah tentunya dengan bantuan kedua orang tua yang membiasakan diri berbicara bahasa Inggris di rumah.

Suasana yang menyenangkan adalah Syarat mutlak yang diperlukan supaya anak suka belajar. Menurut hasil penelitian tentang cara kerja otak, bagian pengendali memori di dalam otak akan sangat mudah menerima dan merekam informasi yang masuk jika berada dalam suasana yang menyenangkan.

Selain itu, kenali tipe dominan cara belajar anak apakah tipe Auditory (anak mudah menerima pelajaran dengan cara mendengarkan), Visual (melihat) ataukah Kinestetic (fisik). Meminta anak secara terus menerus belajar dengan cara yang tidak sesuai dengan tipe cara belajar anak nantinya akan membuat anak tidak mampu secara maksimal menyerap isi pelajaran, sehingga anak tidak berkembang dengan maksimal. Anak akan menjadi sangat antusias dan semangat untuk belajar jika isi/materi yang dipelajari anak sesuai dengan perkembangan anak. Anak akan menjadi mudah bosan 
jika yang dipelajari terlalu mudah baginya, dan sebaliknya anak akan menjadi stress dan patah semangat jika yang dipelajari terlalu sulit.

Ada beberapa hal yang mungkin bisa dilakukan untuk mengajarkan bahasa inggris dirumah pada anak. Berikut adalah beberapa hal yang bisa dilakukan orang tua:

1. Memakai media Buku bergambar

Metode ini dapat membuka dunia baru untuk anak-anak yang belajar bahasa Inggris.

2. Memperdengarkan Lagu dan sajak

Cara yang menyenangkan untuk mengingat kata-kata dalam bahasa Inggris adalah melalui pengulangan sajak dan lagu.

3. Membaca dengan suara keras (read aloud)

Cobalah membaca buku bergambar dengan suara keras dan tentukan bagaimana Anda akan membuat cerita tersebut menjadi lebih hidup. Ada buku yang tuntas membahas tentang Read Aloud, judulnya Read Aloud Handbook, karya Jim Trelease, penerbit Hikmah ${ }^{8}$.

4. Sudut Inggris atau meja Inggris Anda dapat mengatur area rumah yang terfokus pada apa pun yang berhubungan dengan sesi bahasa Inggris: permainan, perpustakaan mini berisi buku bergambar, pajangan budaya Inggris seperti foto dan bendera, pajangan berupa gambar, buku buatan sendiri, atau hasil kerajinan. Gunakan bahasa inggris untuk menamai atau menunjuk benda.

\section{Metode Mengajarkan Bahasa Inggris Pada Anak dalam Kelas \\ Sebenarnya \\ proses}

pembelajaran itu dapat dilakukan di rumah dengan melibatkan orang-orang di sekitar anak tersebut seperti orang tua atau caretaker. Orang tua dapat mengambil peran aktif untuk memperkenalkan Bahasa Inggris kepada putra putrinya sejak dini. Tentu saja materi pembelajaran itu perlu dikemas sedemikian rupa sehingga anak tertarik untuk mempelajarinya. Tanpa disadarinya ketika sedang bermain, anak tersebut telah masuk dalam proses pembelajaran. Berikut ini adalah kegiatan pembelajaran Bahasa Inggris yang dapat dilakukan di rumah. Adapun cara belajar bahasa inggris bagi anak bisa dilakukan dengan cara berikut:

\section{Lihat dan katakan}

Dalam metode ini anak-anak belajar mengenali kata-kata atau kalimat-kalimat keseluruhan, bukannya bunyi-bunyi individu. Mereka memandangi kata-kata, mereka mendengar kata itu diucapkan, dan kemudian mereka mengulangi ucapan itu. Dengan cara ini anak-anak dapat memperoleh makna dari dalam katakata tercetak dari tahap paling awal belajar membaca. 


\section{Metode Pendukung Konteks}

Bila anak-anak sedang belajar membaca, sangatlah penting bahwa mereka menggunakan buku yang benarbenar menarik bagi mereka.

\section{Fonika (Metode Fonik)}

Metode ini mengandalkan pada pelajaran alfabet yang diberikan terlebih dulu kepada anak-anak, mempelajari nama-nama huruf dan bunyinya. Setelah mereka mempelajari bunyi huruf mereka akan mulai merangkum beberapa huruf tertentu untuk membentuk kata-kata.

\section{b-a-k r-a-k p-a-k f-a-k}

Untuk memberikan latihan baca kepada anak-anak dalam ketrampilan ini, buku-buku cerita haruslah agak terencana, sehingga semua kata bersifat regular dan dapat dibunyikan. Luar biasa sukarnya untuk menulis buku dengan kata-kata yang secara fonik bersifat regular, yang menarik untuk dibaca anak-anak.

Ada kekurangan dalam menggunakan metode fonik sebagai pendekatan pertama untuk membaca. Mempelajari bunyi yang terpencil sangat abstrak bagi anak kecil. Ini tidak berarti apa-apa biasanya mereka menganggapnya sebagai aktivitas yang membosankan. Mereka juga harus benar-benar memusatkan pikiran akan pembunyian kata-kata sehingga mereka tidak mampu berpikir mengenai maknanya. Mungkin untuk mengucapkan kata dengan benar tanpa mempunyai gambaran akan artinya. Anak-anak yang diajar hanya dengan metode ini akan belajar dan mengucapkan kata-kata tak bermakna dengan sangat benar, sedangkan jika kata-kata itu dalam kalimat mereka segera tahu bahwa kata-kata itu tidak berarti. Karena alasan-alasan inilah metode fonik biasanya tidak diajarkan sampai anak-anak dapat memahami dengan baik dasar-dasar membaca. Tetapi anak-anak yang lebih besar yang merasakan kesukaran membaca, sering merasa pendekatan fonik ini baik bagi mereka. Tidak ada bukti pasti bahwa salah satu metode itu lebih unggul daripada yang lain. Kebanyakan guru cenderung menggabung sejumlah metode yang berlainan. Anak-anak yang berlainan memperoleh manfaat dari metode yang berlainan pada tahap yang berlainan.

Beberapa kelebihan dari metode ini adalah: (1). dapat diajarkan dengan struktur bahasa yang disesuaikan dengan kaidah linguistik dan perkembangan bahasa anak. (2) Dapat dilakukan di sekolah dan di rumah. (3). Dilaksanakan sesuai dengan kerja otak anak; tidak memaksa, bermakna dan kontekstual. (4). Anak paham bahasa Indonesia bukan hanya sekadar bisa membaca. (5). Mengajarkan cara menulis yang proporsional dengan cara yang menyenangkan. ${ }^{9}$

${ }^{9}$ Lili Ardas. (2012).Belajar Membaca Dengan MetodeFonik.[Online].Tersedia:http://lilyardas.wor dpress.com/2012/03/13/metode-fonik/[18 Agustus 2014] 
4. Metode TPR (Total Physical Response Method)

Dikembangkan oleh James Asher, seorang profesor psikologi Universitas Negeri San Jose California, adalah metode yang sesuai untuk mengajarkan bahasa Inggris pada anak usia dini dimana pembelajarannya lebih mengutamakan kegiatan langsung berhubungan dengan kegiatan fisik (physical) dan gerakan (movement). ${ }^{10}$

\section{Teaching English by Using Song}

Adalah salah satu metode / cara mengajarkan bahasa inggris dengan menggunakan nyanyi / lagu sebagai medianya.

Pada hakikatnya nyanyian bagi anak-anak adalah sebagai bahasa Emosi, dimana dengan nyanyian anak dapat mengungkapkan perasaannya, rasa senang, lucu, kagum, haru. Bahasa Nada, karena nyanyian dapat didengar, dapat dinyanyikan, dan dikomunikasikan ${ }^{11}$.

Bahasa Gerak, gerak pada nyanyian tergambar pada irama (gerak/ ketukan yang teratur), pada irama (gerak/ketukan panjang pendek, tidak teratur), dan pada melodi (gerakan tinggi rendah).

\section{Teaching English by using Games}

Dalam pembelajaran Bahasa Inggris banyak metode dan teknik yang dapat digunakan, diantaranya melalui:

\footnotetext{
${ }^{10}$ Salman Rusydie. 2012. Kembangkan Dirimu Jadi Guru Multitalenta.Diva Press. Jakarta ${ }^{11}$ Idem
}

a. Story Telling (Bercerita)

b. Role Play (Bermain Peran)

c. Art and Crafts (Seni dan Kerajinan Tangan)

d. Games (Permainan),

e. Show and Tell,

f. Music and Movement (Gerak dan Lagu) di mana termasuk di dalamnya Singing (Nyanyian). ${ }^{12}$

\section{Teaching English by using Stories}

Belajar Bahasa Inggris dapat dilakukan dengan berbagai cara, salah satunya adalah dengan membaca cerita pendek berbahasa Inggris. Dengan membaca kalimat perkalimat bahasa inggris tetapi yang masih mudah dipahami akan sangat membantu kita dalam memahami cerita berbahasa inggris tersebut.

\section{Metode Fonik Dalam Pembelajaran Bahasa Inggris}

Metode fonik menekankan kata melalui proses mendengarkan bunyi huruf. Pada mulanya anak diajak mengenal bunyi-bunyi huruf kemudian huruf-huruf Tersebut menjadi suku kata dan kata. Untuk memperkenalkan bunyi berbagai huruf biasanya mengaitkan huruf - huruf tersebut dengan huruf depan berbagai nama benda yang sudah dikenal anak seperti huruf a dengan gambar ayam, huruf $\mathbf{b}$ dengan gambar buku, dan seterusnya. Menurut Thahir (2007) membaca pada metode fonik memiliki tiga tahapan yaitu:

12 Salman Rusydie. 2012. Kembangkan Dirimu Jadi Guru Multitalenta.Diva Press. Jakarta 
1)Tahap merah Membaca dengan suku kata terbuka contoh: Mata, papa, mama.

2) Tahap biru Membaca kata yang mengandung suku kata tertutup contoh: motor (mo-tor), jendela (jen-dela). 3) Tahap hijau Membaca kata yang mengandung suku kata double vokal dan doble konsonan. Contoh double vokal: pakai (pa-kai), pulau (pu-lau). Contoh double konsonan: nyenyak (nyenyak), bintang (bin-tang), struktur (struktur). Berdasarkan uraian di atas, tujuan dari penelitian ini adalah dengan menggunakan metode fonik dapat meningkatkan kemampuan berbahasa bagi anak usia dini ${ }^{13}$.

Metode fonik adalah metode membaca dengan melafalkan bunyi dari huruf sesuai dengan fonetiknya, sehingga memudahkan anak membaca. Ditambah lagi dengan teknik - teknik mengajar yang sangat dekat dengan dunia anak, sehingga membuat anakanak tidak bosan dan menumbuhkan gemar membaca.

Adapun beberapa keunggulan metode ini secara singkat di jabarkan sebagai berikut:

1. Hanya 1 - 6 anak / kelas

2. Menumbuhkan gemar membaca pada anak

3. Sudah terbukti efektif dan sudah digunakan oleh ribuan anak.

4. Dengan 3 huruf, sudah mulai bisa membaca

${ }^{13}$ Leni Nofrienti. 2012. Peningkatan kemampuan membaca anak melalui metode fonik Di taman kanak-kanak islam adzkia Bukittinggi.
5. Tersedia juga seminar \& pelatihan mengajar untuk ayah, ibu dan para guru. $^{14}$

Berdasarkan data yang kami peroleh dari kegitan observasi dan interview yang dilakukan oleh peneliti ini bahwa lembaga ini menggunakan panduan dalam metode ini yaitu CBIF (Cerdas Berbahasa Inggris dengan metode Fonik). Diketahui pula bahwa metode pembelajaran fonik ini di lakukan dengan memperhatikan level dari masing masing siswa. Masing masing level ini menerima treatment pembelajaran bahasa Inggris yang berbeda. Selain itu siswa belajar dengan alat peraga yang berbeda yang tentunya sesuai dengan level mereka. Adapun level yang peneliti ketahui ada tiga pembagian level pada pembelajaran bahasa inggris melalui metode fonik di PAUD yaitu:

\section{a. Level satu (untuk PAUD usia 2,5 tahun ke atas)}

Penggunaan metode fonik dalam level ini adalah ternyata mampu untuk: (1) Memberi pemahaman bahwa tiap huruf mempunyai bunyi yang berbeda. Adanya perbedan bunyi vocal dan konsonan atau perbedaan bunyi pada masing-masing kategori tersebut. Contoh huruf B (eb/beh), P (ep/peh), $M(e m), N(e n), E(i, e i, i e)$ dan lainnya. (2) Huruf konsonan akan berbunyi jika ditemani dengan huruf vocal. Huruf konsonan bisa berbunyi menjadi satu

${ }^{14}$ http://www.easyreaderhouse.com/main .php?hal=program 
suku kata jika mengalami penambahan huruf vocal sebagai syllable nuclei atau unsur pembuat syllable. Contoh ma $(e m+a=m a), \quad(e l+a=l a) \quad$ dan $\quad(e p+a=p a)$ dalam hal ini mereka dikenalkan dulu dengan baik tentang apa saja bunyi konsonan dan apa saja bunyi vocal mulai dari bentuk dan bunyinya. (3) Setiap huruf mempunyai pasangan huruf yaitu huruf capital dan huruf besar. Dalam pengenalan ini siswa tidak hanya melihat gambar huruf tapi juga bisa meraba huruf dan menulisnya. Contoh huruf $\mathrm{M} / \mathrm{m}, \mathrm{N} / \mathrm{n}, \mathrm{G} / \mathrm{g}, \quad \mathrm{K} / \mathrm{k}$ dan seterusnya.

Adapun pada level satu ini dengan diajarkannya hal tersebut diatas siswa mempunyai kemampuan sebagai berikut; (1) siswa mampu menunjukkan huruf sesuai dengan bunyinya. Siswa bukan menghafal tapi memahami betul bentuk dan bunyi huruf yang telah diajarkan. (2) Meraba huruf sesuai dengan alur penulisan sebagai latihan menulis. Hal ini dilakukan dengan alat peraga berupa huruf terpisan dimana ujung jari mereka dituntun untuk meraba dan merasakan bentuk hurufnya. (3) Menyusun bunyi menjadi satu suku kata atau menyusun suku kata menjadi kata. Contoh kata apple di perkenalkan dengan cara (ei+pel=eipel), (keh+eit), (beh+uk=buuk) dan yang lainya.

Berikut adalah bagaimana alat peraga digunakan dalam level ini adalah sebagai di gunakan sebagai berikut:

\section{(1). Penggunaan alat peraga Huruf} Raba.

Dengan alat ini guru mengajarkan huruf sesuai dengan bunyinya dan cara penulisannya. Alat ini telah membantu anak memahami bentuk huruf dan bunyinya bukan sekedar menghafal. Hal pertama yang di raba oleh anak adalah pengenalan bentuk persegi dan persegi panjang. Baru guru mengenalkan dan mempersilakan siswa untuk meraba. Peneliti melihat bahwa alat peraga itu terdiri dari dua bentuk yaitu persegi dan persegi panjng. Persegi digunakan untuk huruf setengah baris dan persegi panjang untuk huruf panjang ke bawah seperti huruf J,g,y. guru juga memberi warna yang berbeda untuk bunyi consonant dan bunyi vocal. Belajar fonik dengan menggunakan alat peraga ini ternyata menyenangkan dan tidak membuat siswa merasa bosan. Guru menggunakan huruf raba ini dengan cara (1) guru memisahkan huruf vocal dan huruf konsonan (2) guru mengambil tumpukan huruf vocal (3) guru mengambil huruf "o" dan menunjukkannya ke anak-anak (4) guru mengatakan huruf "O" dan memberi contoh dalam kata "go" (5) guru menunjukkan cara menulis hurufnya kepada siswa dan meminta anak untuk mencontohnya (6) meminta anak mengulanginya sekali lagi dan guru mengeceknya satu persatu, kadang sesekali guru bertanya apakah kata "long" terdengar ada "o" nya? Bila anak masih merasa bingung guru menanyakannya kembali dan memberi 
contoh yang lain. Dengan ini anak bisa memahami bunyi setelah 12 kali meraba dan 20 kali mendengar kata yang ada bunyi huruf yang sedang dipelajari. Guru melakukan ini terhadap bunyi vocal lainnya. Setelah itu baru huruf konsonan. Anak-anak terlihat lebih paham.

\section{(2). Huruf pisah fonik}

Pada penggunaannya, huruf pisah fonik yang merupakan alat peraga yang berbentuk huruf kecil dan huruf capital. Terbuat dari karet dengan dua kode warna. Warna biru untuk konsonan dan biru untuk vocal. Penyajian huruf disusun sesuai dengan kode warna dan bentuk agar anak tidak menghafal tapi mengerti akan hubungan bunyi dan bentuk huruf. Dengan ini, anak mengenal semua huruf tapi mengalami kesulitan menggabungkan menjadi suku kata dan kata. Setiap huruf vocal disediakan sebanyak 10 buah dan huruf konsonan 7 buah. Hal ini dimaksud agar anak bisa membuat kata dengan leluasa baik untuk bahasa Indonesia, bahasa Inggris dan bahasa lainnya yang menggunakan huruf Latin. Contoh: mengenalkan kata a-p-p-l-e berasal dari penyatuan a-p-p-l-e yang terpisah. Berikut ini adalah hal yang dilakukan oleh guru untuk mengajarkan metode fonik ini.

1. Guru meletakkan huruf di depan anak. Sambil membuka tutupnya dan temukan garis dibalik tutup. Garis itu berguna untuk menyusun kata.
2. Contoh ketika Katakan: "ibu ingin bunyi 'ma'. Kira-kira bunyi apa saja dari kata "ma"

3. Bila anak tidak mengalami kesulitan, lakukan latihan sebagai berikut: "kalau kita akan menulis kata "pen" atau "book" guru akan bertanya lagi "cocoknya kata itu dipakai waktu apa? Guru meneruskan anak bisa melakukannya lanjutkan dengan membuat kata yang lain seputar bunyi pen dan book.

Peraga ini membuat anak bisa melakukannya membuat kata yang lain seputar bunyi "p" dan vocal; papa, mama, dan lainnya. Latihan ini bisa dilakukan ketika anak sudah mengenal semua bunyi vocal dan salah satu bunyi konsonan. Jika lakukan secara simultan dengan perkembangan penguasaan anak terhadap bunyi konsonan. Dengan cara ini, anak akan merasa bermakna, dan percaya diri bahwa ia sudah bisa membaca Lakukan bunyi suku kata terbuka dulu, suku kata tertutup dan kata yang menggandung bunyi vocal rangkap dan konsonan rangkap seperti; ai "pandai". Latihan ini bisa dilakukan ketika anak sudah mengenal semua bunyi vocal dan salah satu bunyi konsonan. Guru melakukan secara simultan dengan perkembangan penguasaan anak terhadap bunyi konsonan. Dengan cara ini, anak merasa bermakna, percaya diri bahwa ia sudah bisa membaca Lakukan bunyi suku kata terbuka dulu, suku kata tertutup dan kata yang menggandung bunyi vocal rangkap dan konsonan rangkap. 


\section{(3). Label dan Benda Fonik}

Label dan Benda Fonik adalah sejumlah benda yang namanya mengandung suku kata terbuka pita kasa dan label sesuai dengan nama bendanya Alat ini bertujuan memberikan pemahaman kepada anak tentang makna kata yang diwakili dengan benda kongkret. Dengan cara ini anak akan tahu kalau setiap kata memiliki makna.

Dalam penerapannya guru melakukan langkah-langkah berikut:

1. Guru menunjukkan ke anak bendabenda yang tersedia.

2. Guru meminta anak untuk memilihnya lalu menyebutkan namanya.

3. Guru meminta anak untuk mengeja nama benda; misalnya anak mengambil gambar. Guru bertanya: "Itu benda apa?" Anak menjawab Pita Guru melanjutkan pertanyaan Pada kata pita ada bunyi apa saja? Anak menjawab $p$ it a

4. Guru meminta anak untuk mengambil huruf yang menyusun kata tersebut.

5. Jika anak sudah dapat menyusun dengan tepat, mintalah anak untuk memilih label yang sesuai. Lanjutkan dengan benda berikutnya. Untuk memperbanyak kosa kata anak, benda-benda di sekitarnya seperti bola, meja bisa juga dijadikan sebagai alat peraga untuk benda kongkret. Jika anak telah mahir lanjutkan dengan benda yang mengandung suku kata tertutup dan benda yang mengandung vocal rangkap dan konsonan rangkap seperti "boy"/"boi", "coin"/"coin".

\section{(4). Lembar Fonik Kecil}

Guru menggunakan alat ini pada anak yang telah mengenal salah satu bunyi huruf. Alat ini bertujuan untuk membantu anak mengingat bunyi yang dipahami dan menghubungkan dengan gambar yang ada di lembaran terdiri dari dua bagian yaitu lembar vocal dan lembar konsonan.

Guru menggunakan alat ini dengan cara; Guru meminta anak untuk membuka lembar vocal. Kemudian, guru mengucapkan bunyi yang sudah dikuasai anak; misalnya anak telah mengenal bunyi o. Guru berkata "Tolong tunjukkan mana gambar yang namanya ada bunyi "o". Bila anak mengalami kesulitan, guru akan menunjukkan gambar yang ada bunyi o. Kemudian, guru berkata: "Ini gambar apa?" (Guru/orang tua) menunjuk gambar bola. Dan, bila anak bisa menyebutkan bantu anak untuk mengejanya. "Ini gambar "ball'/'bol'. Jadi ada tidak bunyi O-nya?", guru akan melakukan latihan ini sampai anak bisa memahami bunyi pada kata.

\section{(5). Lembar Fonik Besar}

Lembar ini sebaiknya selalu ditempel di dinding yang terjangkau oleh pandangan mata anak. Alat Ini bertujuan untuk membantu anak melihat bentuk yang lebih besar dan yang ia pegang. Lembar ini di pasang di kelas atau di ruang belajar anak.

\section{Level $\mathbf{2}$ untuk Usia 4 tahun ke atas \\ Tujuan Pembelajaran pada} tahapan ini adalah anak mengerti atau 
mendapat pemahaman yang lebih dalam pemahaman bahasa inggris dengan metode fonik. Jadi, pada tahapan ini siswa sudah diharapkan memahami: (1) Tiap kata memiliki makna dan siswa di harapkan untuk bukan hanya bisa baca tapi juga bisa memahami kosa kata yang diajarkan contoh kata "mother" adalah ibu yang melahirkan kita, menjaga kita dan merawat kita. (2) Kata yang tulisannya sama ketika dibaca dengan bunyi yang berbeda memiliki makna yang berbeda pula contoh; 'can' memiliki pengucapan yang sama tapi arti yang berbeda. (3) Kata bisa beda makna hanya dengan perbedaan satu bunyi saja. Dengan metode fonik ini siswa di berikan pemahaman mendalam tentang bunyi foniknya bukan hanya huruf alfabetnya. Contoh kata "back/bek" berakhiran ' $k$ ' yang berarti punggung berbeda makna dengan "bag/beg", berakhiran " $g$ " yang berarti tas. (4) Dengan ini diharapkan siswa lancar membaca dan tahu maknanya. (5) Mampu membedakan kata yang bermakna dan tidak. (6) Membedakan nama orang dan nama selain orang. (7) Kata yang tulisannya sama ketika dibaca dengan bunyi yang berbeda memiliki makna yang berbeda pula. (7) Kata bisa beda makna hanya dengan perbedaan satu bunyi saja. (8) membedakan nama selain nama orang.

Adapun alat peraga dan cara pembelajarannya adalah sebagai berikut:

\section{Kartu dan Label Fonik}

Menurut informasi dari kepala sekolah, Kartu dan Label Fonik adalah data peraga yang berbentuk kartu gambar dan label name gambar. Kartu ini berguna untuk melancarkan anak membaca dan mengerti bahwa setiap kata ada makna yang ditunjukkan dengan gambar. Banyak cara penyajian pembelajarannya dalam kartu ini. Salah satunya adalah sebagai berikut:

a. Guru mencari 3 anak untuk bermain kartu bersama temannya di kelas.

b. Guru mengocok kartu gambar dan meletakkan secara tertutup

c. Guru mengocok kartu label dan bagikan ke masing-masing anak.

d. Guru meminta anak untuk mengambil kartu gambar secara bergiliran.

e. Bila gambar yang diambil cocok dengan kata yang ada berarti pemain mendapatkan poin. Kartu ini juga bisa di pakai untuk permainan yang lain seperti: Memory game, acak kartu, dan sejenisnya.

\section{Set Gambar Fonik}

Alat peraga ini berbentuk lembaran yang berisi gambar gambar dan label secara terpisah. Ada 6 lembar kartu dan 6 set label. Alat ini berguna untuk memperkaya kosa kata anak dan melatih konsentrasi anak. Sedangkan cara pembelajarannya adalah sebagai berikut:

a. Pertama guru menunjukkan 6 lembar kartu gambar.

b. Guru meminta anak untuk memilihnya. Bila anak mengalami kesulitan mulailah dengan yang berwarna merah.

c. Guru menyimpan Label 
d. Bila anak telah memilih salah satu lembar, guru meminta anak untuk menyebut masing-masing gambar yang ada.

e. Bila nama gambar yang disebutkan anak tidak sesuai dengan label yang ada, maka guru akan mengarahkan anak sampai sesuai dengan label yang ada. Misalnya anak menyebut gambar tangan 'hand' padahal yang dimaksudkan jari 'finger'. Guru berkata: "Yang saya maksudkan bagian tangan yang ini (sambil menunjuk jari 'finger')."

f. Setelah anak bisa menyebutkan nama gambar sesuai dengan label

g. Guru memberikan satu set label dan minta anak untuk mencocokkan dengan gambar yang ada.

Untuk anak yang aktif latihan ini kadang dilakukan di ruang terbuka dengan cara mencocokkan label dengan gambar yang diletakkan secara berjauhan. Latihan ini kadang bisa juga dilakukan secara kelompok.

\section{Daftar Kata Fonik}

Alat peraga ini berbentuk lembaran yang berisi daftar kata. Ada 6 lembar daftar kata. Alat ini berguna untuk memperkaya kosa kata anak, melatih konsentrasi anak dan melatih membaca lancar.

Sedangkan proses pembelajaran menggunakan kartu ini dilakukan dengan beberapa langkah seperti berikut:

a.Guru menunjukkan 6 lembar daftar kata.
b.Guru meminta anak untuk memilinnya. Bila anak mengalami kesulitan guru akan meminta anak untuk mulai dari yang warna merah.

c. Bila anak telah memilih salah satu lembar, mintalah anak untuk menyebut gambar yang ada. Gambar menunjukkan pola kata yang ada di bawahnya.

d. Guru meminta anak untuk membaca secara individual.

\section{Buku Kecil Fonik}

Alat peraga ini berbentuk buku kecil. Ada 6 buah buku kecil. Alat ini berguna untuk memperkaya kosa kata anak, melatih konsentrasi anak, melatih membaca lancar dan melatih anak membuka buku dengan tepat.

Dengan alat peraga ini guru bisa lebih memperkaya kosa kata siswa dalam bahasa Inggris. Adapun langkah atau proses pembelajarannya adalah sebagai berikut:

a. Guru menunjukkan 6 buku kecil yang berwarna berisi beberapa kosa kata bahasa Inggris.

b.Guru meminta anak untuk memilinnya. Bila anak mengalami kesulitan mulailah dengan yang warna merah.

c. Guru menunjukkan cara membuka buku dengan benar yaitu dimulai dari sudut kanan atas ke bawah.

d.Guru meminta anak untuk mempraktekkannya.

e. Guru meminta anak untuk membaca judul dan dilanjutkan dengan membaca kata yang ada di dalam buku. 
f. Guru membiarkan anak yang telah menyelesaikan satu buku untuk mendapat penghargaan: 'Selamat atas usahamu, kamu telah berhasil membaca satu buku. Apakah kamu mau melanjutkannya?"

g. Bila anak masih bersemangat guru memberikan kesempatan anak untuk membaca buku berikutnya.

\section{Buku Aktivitas Menulis}

Buku ini dirancang untuk melatih anak menulis. Guru akan memberikan buku ini kepada anak yang sudah terlihat bisa berlatih menulis kosa kata bahasa Inggris. Adapun ciri-ciri anak yang telah siap berlatih menulis adalah sebagai dan diperbolehkan memakai buku fonik type ini adalah: 1) anak yang sudah bisa memegang pensil dengan benar. 2) anak yang sudah bisa membuat garis lurus, lengkung dan zigzag. Buku ini sebenarnya tepat sekali bila dikerjakan bersama orang tua di rumah namun adakalanya di kerjakan pula di sekolah.

\section{Buku aktivitas membaca}

Buku ini dirancang untuk latihan anak membaca secara mandiri. Biasanya buku ini diberikan oleh guru sebagai latihan anak secara mandiri. Guru memberikan kepercayaan anak untuk berlatih dan menyiapkan jawaban yang nyaman bila anak mengalami kesulitan.

\section{Level 3 Untuk Anak Usia 6 Tahun}

Pada tahapan usia ini anak-anak sudah mendapat perlakuan yang lebih intensif. Guru mulai dengan kata yang disusun secara bermakna untuk membentuk frase, setelah itu dari katakata tersebut dibentuklah Frase yang sempurna disebut kalimat. Contoh; kata "andi, eat, apple" akan menjadi "andi eats apple". Kata tugas diperlukan dalam sebuah kalimat. Kalimat yang dibaca dengan intonasi yang berbeda akan berpengaruh terhadap makna. Anak bisa memiliki kemampuan untuk membedakan kata, frase, kalimat dan paragraf, membaca dengan intonasi sesuai dengan tanda baca dan menjelaskan makna kata yang dibaca.

Adapun alat Peraga dan Cara Pembelajaran yang di terapkan pada pembelajaran bahasa Inggris dengan sistem fonik ini adalah sebagai berikut:

\section{Kata Tugas}

Alat peraga ini berbentuk lembaran yang berisi daftar kata tugas. Ada 2 lembar daftar kata tugas. Alat Ini berguna untuk memperkaya kosa kata anak, mengenalkan kata tugas. Adapun cara pembelajarannya adalah sebagai berikut:

a. Guru menunjukkan 2 lembar daftar kata tugas.

b. Guru meminta anak untuk memilihnya.

c. Guru meminta anak untuk membaca secara individual.

d. Bila anak mengalami kesulitan membaca guru membantu dengan sebaik-baiknya.

Daftar kata tugas tidak harus selesai dalam satu pertemuan. Berikan latihan anak untuk membedakan mana kata konsep dan mana kata tugas. 
Sampaikan kepada anak bahwa kata tugas hanya memiliki makna bila dipakai dalam kalimat.

\section{Kata Seru}

Alat peraga ini berbentuk kartu panjang yang berisi kata seru dan kalimat thayibah yang biasa diajarkan untuk anak-anak.

a. Tunjukkan cara membuka buku dengan benar yaitu dimulai dari sudut kanan atas ke bawah.

b. Guru meminta anak untuk mempraktekkannya.

c. Guru meminta anak untuk membaca judul dan dilanjutkan dengan membaca kata yang ada di dalam buku.

d. Jika anak telah menyelesaikan satu buku maka guru memberikan penghargaan: 'Selamat atas usahamu, kamu telah berhasil membaca satu buku dan mengingat banyak kosakata. Apakah kamu mau melanjutkannya?" Bila anak masih bersemangat guru berikan kesempatan anak untuk membaca buku berikutnya.

\section{Kalimat Fonik}

Alat peraga ini berbentuk kartu memanjang. Satu kartu berisi satu kalimat. Ada 2 bentuk kartu kalimat yaitu kartu kailmat sambung dan kartu kalimat pisah. Kartu Ini berguna untuk mengenalkan anak tentang bentuk kalimat, cara menulis kalimat yang selalu diawali dengan huruf capital dan diakhiri dengan titik, dan cara membaca kalimat.
Kartu ini di gunakan dengan cara sebagai berikut:

a. Guru menunjukkan 2 jenis kartu kalimat.

b. Guru memisahkan kartu kalimat sambung dan kartu kalimat pisah.

c. Guru memberikan kesempatan anak untuk mencoba kartu sambung.

d. Guru memberikan gambar dan kartu kalimat pisah. Guru meminta anak memilih kalimat yang sesuai dengan gambar yang ada.

\section{Buku Cerita Fonik}

Ada 3 buku cerita yang dirancang untuk anak membaca secara mandiri. Buku ini berguna untuk mengajarkan membaca mandiri, mengenal tanda baca, dan mengenal pemakaian huruf capital. Adapun cara pembelajaran dengan buku ini adalah sebagai berikut:

a. Tunjukkan 3 buku kepada anak dan biarkan la memilih buku cerita berbahasa inggris tersebut.

b. Guru mengingatkan untuk membuka buku dengan tepat sebagaimana la berlatih membuka buku kecil.

c. Guru menunjukkan bagian-bagian buku, judul, penerbit, penulis, illustrator.

d. Guru memberikan kesempatan untuk membaca.

e. Bila anak membaca tanpa Intonasi guru/orang tua bisa memberikan contoh.

f. Setelah selesai guru berikan pertanyaan: "Mengapa kata ini memakai huruf kapital? Ini tanda 
apa? Mana tanda koma? Bagaimana cara membacanya?"

Bila anak telah menyelesaikan semua level anak sudah siap membaca buku lainnya. Berikan ia kesempatan untuk membaca dan kenalkan tata bahasa secara sederhana.

\section{Alat Assesment dengan Metode Fonik}

Adapun assessment yang dipakai untuk metode ini adalah sebagai berikut:

a. Kartu Prestasi. Kartu prestasi diisi untuk mencatat perkembangan yang sudah dilalui anak. Kartu Ini berfungsi sebagaimana rekam medis.

b. Alat Ukur Membaca. Alat ukur membaca digunakan setelah anak menyelesalkan level 2. Semua cara pembelajaran yang ada bersifat Inspiratif. Cara sebaiknya disesuaikan dengan kondisi dan tempat belajar anak.

\section{Kendala dalam penerapan Metode Fonik}

Adanya kendala yang dihadapi oleh guru PAUD dalam pelajaran bahasa Inggris dengan sistem fonik adalah

a. Bahwa sistem ini membutuhkan ketelatenan yang besar dari guru

b. Diperlukan tenaga guru yang menguasai bahasa Inggris dengan benar

c. Lebih lambat pencapaiannya dari pada system hafal dan drilling tapi banyak manfaat dalam jangka panjang. d. Orang tua selalu berharap anaknya cepat mengalami perkembangan pesat dalam bahasa Inggris tanpa mempertimbangkan perkembangan otak dan psikis anak.

\section{Kesimpulan}

Kegiatan belajar yang tidak dilakukan dengan cara memaksakan anak. Kegiatan belajar ini tetap dilakukan dengan cara yang menyenangkan. Metode fonik ini menggunakan alat peraga yang menyenangkan dan mampu menarik perhatian siswa. Metode ini ternyata benar-benar efektif dalam membantu anak membaca dan belajar bahasa Inggris. Dengan metode ini anak bisa lebih fokus dalam belajar karena mereka bisa belajar sambil menggunakan alat peraga. Disamping itu, belajar dengan metode ini juga membuat anak bisa mengingat apa yang mereka pelajari dalam jangka waktu yang lebih panjang. Karena, metode ini bukan metode menghafal tetapi menerapkan metode kebermaknaan. Jadi, anak tidak hanya bisa membaca tapi juga tahu pasti makna dari apa yang mereka baca.

Peran guru sangatlah penting dalam pembelajaran ini. Guru harus telaten dalam menerapkan metode ini. Diperlukan guru yang atraktif dan enerjik dalam melakukan metode ini. Guru harus benar-benar secara jelas melafalkan kata-kata dalam bahasa Inggris ini secara benar. Harus dilakukan berulang-ulang sampai anak bisa membunyikan dan mengerti benar makna yang ada dalam kata tersebut. 
Adapun kendala yang didapat dari penggunaan metode ini adalah kendala waktu, butuh waktu yang lebih lama untuk menerapkan metode ini dari pada metode lain yang dipakai oleh guru PAUD lainnya. Tak jarang karena metode ini banyak orang tua murid yang merasa tidak sabar karena merasa anak mereka mengalami perkembangan yang kurang signifikan.

\section{Daftar Pustaka}

Al-Uswah Centre.(2009).Metode Belajar Fonik.Online].http://aluswahcente r.wordpress.com/2009/05/20/met ode-belajar- membacafonik/[18 Agustus 2014]

Chomsky, N; Skinner, B. F. (1959). "A Review of B. F. Skinner's Language Verbal Behavior" (Linguistic Society of America)

http://www.easyreaderhouse.com/main.p $\mathrm{hp}$ ?hal=program

Latifah Nurfauziah, 2013.Penggunaan Teknik Talking Stick Dalam Meningkatkan Penguasaan Kosakata Bahasa Inggris Anak Usia Dini Universitas Pendidikan Indonesia

|repository.upi.edu|perpustakaan. upi.edu

Leni Nofrienti. 2012. Peningkatan kemampuan membaca anak melalui metode fonik Di taman kanak-kanak Islam adzkia Bukittinggi.

Lili Ardas. (2012). Belajar Membaca Dengan Metode Fonik. [Online].Tersedia:http://lilyardas. wordpress.com/2012/03/13/meto de- fonik/[18 Agustus 2014]
Nunung wijayanti on http://nunungwidijantie.blogspot.c om/2012/06/normal

Plunkett Kim (1998). Rethinking innateness: $A$ connectionist perspective on development. The MIT Press

Salman Rusydie. 2012. Kembangkan Dirimu Jadi Guru Multitalenta. Diva Press. Jakarta 